\title{
KONSEP GEOMETRI FRAKTAL DALAM KAIN TENUN TANIMBAR
}

\author{
Darma Andreas Ngilawajan \\ Program Studi Pendidikan Matematika FKIP Universitas Pattimura \\ Jl. Ir. M. Putuhena, Kampus Unpatti, Poka-Ambon, Indonesia \\ e-mail: dngilawajan@gmail.com
}

\begin{abstract}
Abstrak
Geometri Fraktal adalah cabang geometri yang bertumpu pada dua hal, yaitu kemiripan diri sendiri (selfsimilarity) dan ukuran (dimension). Dari dua hal dasar tersebut maka sebuah objek dapat diproyeksi dalam berbagai ukuran secara berulang sehingga terbentuk suatu pola yang unik. Kain tenun Tanimbar merupakan salah satu produk budaya dari Kabupaten Maluku Tenggara Barat yang telah ada sejak ratusan tahun lalu. Kain tenun ini adalah hasil kerajinan tangan penduduk lokal yang dapat diolah untuk dijadikan pakaian adat, maupun digunakan sebagai kelengkapan dalam berbagai upacara adat di Kepulauan Tanimbar. Kain tenun Tanimbar memiliki pola yang menjadi ciri khas tersendiri dari kain tenun tersebut. Jika diteliti secara seksama, maka pola dari kain tenun Tanimbar dihasilkan dari gambar-gambar yang dibuat berulang yang menyerupai konsep dasar dari geometri fraktal. Tulisan ini akan mengkaji konsep geometri fraktal dalam pola-pola yang terbentuk pada kain tenun Tanimbar. Selain itu pula, untuk mengenalkan salah satu produk budaya dari pulau Tanimbar melalui matematika.
\end{abstract}

Kata Kunci: Geometri, geometri fraktal, kain tenun Tanimbar.

\section{CONCEPT OF FRACTAL GEOMETRY ON PATTERNS OF TANIMBAR'S WOVEN FABRIC}

\begin{abstract}
Fractal Geometry is a branch of geometry which emphasized on two things, which are self-similarity and dimension. The two basic things which made an object to various in size so then those various sizes of the object can be formed to a unique pattern. Tanimbar's woven fabric is one of various cultural products of South East Maluku Regency which has been invented since hundred years ago. Woven fabric is a handy product of local people that can be formed to local fashion which used in daily life and as a feature in traditional ceremonials in Tanimbar Island. Tanimbar's woven fabric has unique characteristic in its pattern. If we take a look precisely, the pattern is formed by iteration of a figure which similar to fractal geometry. This paper intended to discuss about the concept of fractal geometry on patterns of Tanimbar's woven fabric. In addition, it also intended to introduce one of Tanimbar's cultural products through mathematics.
\end{abstract}

Keywords: Geometry, fractal geometry, Tanimbar's woven fabric.

\section{Pendahuluan}

Geometri sebagai salah satu cabang dari matematika, saat ini telah mengalami perkembangan yang signifikan. Indikasi dari perkembangan tersebut terlihat dari lahirnya beberapa cabang geometri di era tahun 70-an yang merupakan pengembangan dari konsep geometri terdahulu, dimana cabang-cabang baru dari geometri tersebut lebih berasosiasi dengan dunia nyata. Salah satu cabang geometri tersebut adalah geometri fraktal.

Geometri fraktal, yang dicetuskan pertama kali oleh Benoit Mandelbrot, memiliki karakteristik tersendiri karena objek kajiannya bukan hanya hasil buatan manusia seperti halnya objek pada geometri Euclidian, tetapi sebagian besar merupakan bentuk-bentuk objek di alam. Dengan kata lain, geometri fraktal merupakan cara alami untuk merepresentasi bentuk-bentuk objek di alam. Mengacu pada karakteristik 
tersebut, maka konsep geometri fraktal hampir selalu dapat kita temukan di lingkungan sekitar kita, misalnya bentuk awan, daun, atau pohon.

Produk fisik dari suatu bentuk kebudayaan merupakan salah satu contoh objek yang dapat kita jumpai dalam keseharian kita, misalnya rumah adat, seni ukiran, patung, kerajinan anyaman, tenunan kain dan sebagainya. Jika dilihat secara seksama, produk-produk fisik dari kebudayaan tersebut memiliki pola khusus yang menjadi ciri khas dari budaya yang menempel pada produk tersebut.

Kain tenun Tanimbar merupakan salah satu produk fisik dari kebudayaan masyarakat di kepulauan Tanimbar, kabupaten Maluku Tenggara Barat. Kain tenun Tanimbar jika dilihat secara teliti maka terlihat suatu pola pada kain tersebut yang terbentuk dari pengulangan suatu bentuk abstrak. Pengulangan suatu objek dalam berbagai ukuran sehingga membentuk suatu pola merupakan konsep dasar dari geometri fraktal, sehingga pola dari kain tenun Tanimbar tentunya dapat dihubungkan dengan konsep geometri fraktal.

Konsep geometri fraktal dalam tulisan ini tidak akan diulas secara mendalam, tetapi dibatasi hanya pada konsep dasar, yaitu definisi dan contoh-contohnya serta kaitannya dengan pola yang ada pada kain tenun Tanimbar.

\section{Tinjauan Pustaka}

\subsection{Geometri Fraktal}

Kata fraktal diadaptasi dari bahasa Inggris, yaitu fractal. Kata fractal sendiri sebenarnya berasal dari bahasa latin, yaitu fractus, yang artinya "patah" atau "rusak". Gaddis dan Zyda dalam [1] menyatakan bahwa Geometri Euclid yang telah ada sebelumnya tidak dapat memuaskan sebagai model untuk menggambarkan objek-objek di alam. Sebagai contoh, jika siapa pun mencoba membuat gambar sebuah objek non reguler pada layar komputer (misalkan sebuah pohon) dengan menggunakan geometri Euclid maka dipastikan hasilnya tidak akan sesuai dengan bentuk pohon yang sebenarnya. Hal ini yang menjadi alasan bagi Mandelbrot untuk menciptakan jenis geometri baru yang dapat memeuhi kebutuhan untuk merepresentasi bentuk dari objekobjek di alam.

Selanjutnya Gaddis dan Zyda dalam [1] menyatakan bahwa kekuatan dari temuan Mandelbrot adalah penelitiannya terhadap teori-teori para matematikawan sebelumnya dan pengembangan dari penerapan teoriteori tersebut. Pada tahun 1975, Mandelbrot menciptakan istilah fractal untuk mendeskripsikan sekelompok fungsi yang pertama kali ditemukan oleh Cantor (Cantor's Dust = debu Cantor), Koch (Koch's Curve = kurva Koch), dan Peano (Peano's Curve = kurva Peano). Mandelbrot melihat bahwa fungsi-fungsi tersebut meletakan dasar-dasar pemikiran yang sangat bernilai sehingga dapat digunakan untuk membuat kreasi dari objek-objek di alam, sebagai contoh garis pantai dan pegunungan. Mandelbrot kemudian memperkenalkan istilah geometri fraktal untuk tipe-tipe objek tersebut. Meskipun Mandelbrot tidak menciptakan teori-teori yang mendasari geometri faktal, namun pemikirannya dalam meramu teori-teori tersebut sehingga menghasilkan suatu model yang akurat untuk mendeskripsikan objek-objek di alam sehingga dia dianggap sebagai tokoh yang menciptakan geometri fraktal.

Mandelbrot dalam [2] mendefinisikan fraktal sebagai suatu fenomena alam atau himpunan matematika yang menunjukkan pengulangan pola yang ditampilkan pada setiap ukuran yang berbeda. Dari pendapat Mandelbrot, maka dapat dikatakan bahwa fraktal dikonstruksi berdasarkan dua hal, yaitu kemiripan diri sendiri (self-similarity) dan ukuran (dimension). Dengan kata lain, fraktal adalah objek yang memiliki kemiripan dirinya sendiri namun dalam skala atau ukuran yang berbeda. Hal ini berarti bahwa suatu objek dikategorikan fraktal jika bagian-bagian dari objek tersebut akan tampak sama dengan dirinya sendiri bila dilihar secara keseluruhan. Gambar-gambar berikut adalah contoh dari fraktal.

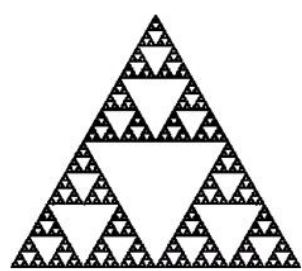

(a)

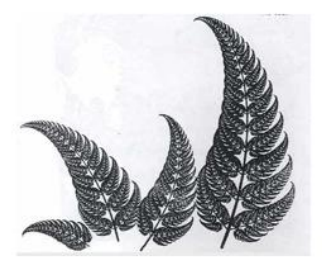

(b)

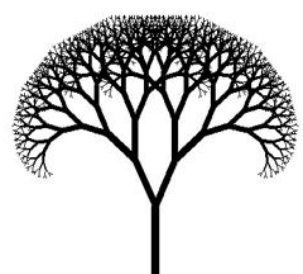

(c)

Gambar 1. (a) Segitiga Sierpinski, (b) Daun Pakis Barnsley, (c) Pohon Fraktal 
Mandelbrot kemudian membuat penjelasan matematis dari fraktal, yang dikenal sebagai Mandelbrot Set (himpunan Mandelbrot), yaitu himpunan bilangan kompleks c sehingga $f_{c}(Z)=Z^{2}+c$ tidak berbeda ketika diiterasi dari $Z=0$. Secara geometris, himpunan Mandelbrot ditunjukkan dalam gambar berikut.

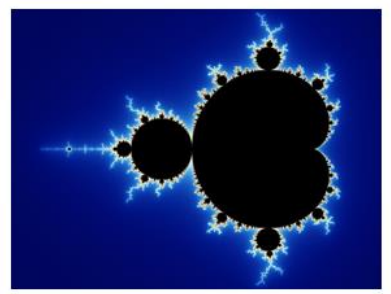

\section{Gambar 2. Himpunan Mandelbrot}

Selanjutnya, Mandelbrot dalam [2] menyebutkan bahwa berdasarkan sumber terbentuknya, maka objek fraktal dapat dibedakan sebagai objek alam dan objek hasil ciptaan manusia. Merujuk pada pendapat tersebut, maka disimpulkan bahwa meskipun ide awal lahirnya geometri fraktal adalah untuk merepresentasi objekobjek di alam, namun objek fraktal tidak selalu merupakan objek-objek di alam, tetapi dapat juga merupakan hasil ciptaan manusia. Contoh sebagian objek fraktal di alam ditunjukkan dalam gambar berikut:

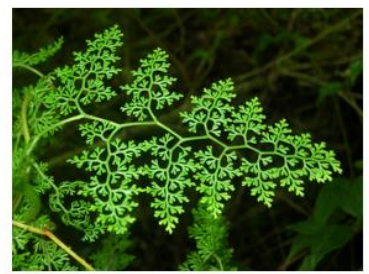

(a)

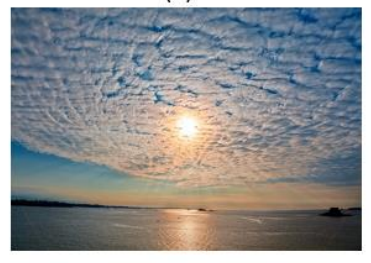

(c)

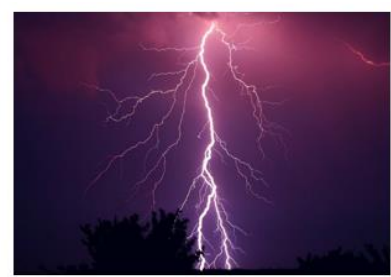

(b)

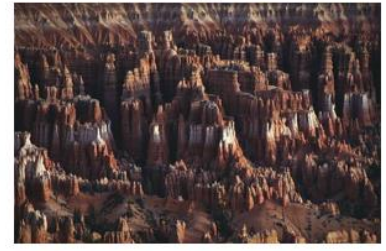

(d)

Gambar 3. Contoh sebagian objek alam yang merupakan fraktal (a) Bentuk daun, (b) Cahaya petir, (c) Awan, (d) Pegunungan

Sedangkan objek buatan manusia yang merupakan fraktal, ditunjukkan dalam gambar berikut:

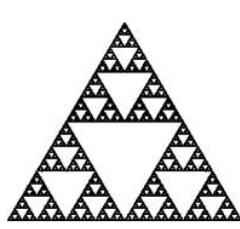

(a)

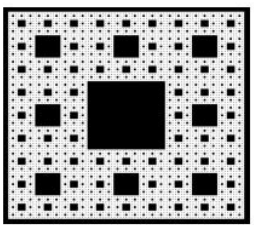

(b)

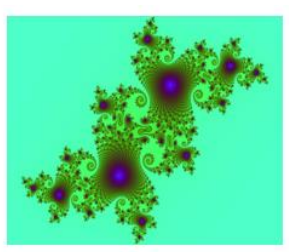

(c)

Gambar 4. Contoh sebagian objek buatan manusia yang merupakan fraktal

(a) Segitiga Sierpinski, (b) Karpet Sierpinski, (c) Himpunan Julia

\subsection{Kain Tenun Tanimbar}

Pulau Tanimbar atau dikenal dengan nama lain Pulau Yamdena adalah salah satu pulau yang terletak di wilayah kabupaten Maluku Tenggara Barat. Pulau Tanimbar memiliki beragam corak budaya yang ditunjukkan melalui sejumlah produk budaya dalam berbagai bentuk, diantaranya adalah kain tenun.

Dalam [3], Van Vuuren menyatakan bahwa sejarah menenun pakaian di pulau Tanimbar telah ada sejak jaman dulu. Awalnya para leluhur orang Tanimbar membuat anyaman dari daun lontar untuk membuat pakaian sebagai penutup tubuh. Dari sini maka disimpulkan bahwa leluhur orang Tanimbar tidak menggunakan cawat seperti daerah lain di Maluku. Selanjutnya, Van Vuuren mengatakan pula bahwa teknik menganyam daun 
lontar sebagai pakaian inilah yang menjadi awal dari teknik menenun kain. Seiring dengan ditemukannya kapas sebagai bahan dasar untuk membuat kain, maka teknik anyaman pada daun lontar ditransformasikan ke teknik menenun pada kain, yang lebih dikenal dengan nama tenun ikat Tanimbar.

Joseph dalam [4] mengatakan bahwa pekerjaan menenun kain merupakan ketrampilan yang diwariskan secara turun-temurun pada kaum wanita Tanimbar. Ketrampilan menenun, selain sebagai sumber untuk mencari nafkah, juga merupakan keharusan adat kepada generasi wanita sebelum memasuki jenjang perkawinan. Sehingga dapat dikatan bahwa keterampilan menenun merupakan warisan dari orang tua kepada anaknya, dimana sebelumnya ketrampilan menenun yang dimiliki orang tua juga diwariskan dari generasi sebelumnya.

Selain sebagai penutup tubuh, kain tenun Tanimbar juga memiliki banyak fungsi yang terkait dengan adat istiadat di Tanimbar. Van Vuuren dalam [3] menyatakan bahwa fungsi kain tenun Tanimbar bukan saja sebagai bahan untuk pakaian, tetapi lebih banyak digunakan dalam upacara-upacara adat, misalnya pada upacara perkawinan, pemujaan arwah leluhur, upacara kematian, dan sebagainya. Pada upacara-upacara tersebut, kain tenun digunakan sebagai persembahan atau sebagai objek pelengkap dalam ritual adat yang dilakukan.

Menurut Joseph [4] corak atau pola yang ada pada kain tenun Tanimbar bukan cuma sebagai motif hiasan, tetapi memiliki nilai dan arti tertentu. Corak atau pola pada kain tenun merupakan hal-hal yang digemari dan dialami oleh para leluhur selama mereka masih hidup. Pola yang ada pada kain tenun pada umumnya merupakan corak dekoratif dan berfungsi sebagai pemujaan terhadap roh-roh tertentu, atau juga menceritakan kehidupan para leluhur yang diciptakan secara simbolik dalam bentuk-bentuk abstrak. Bentukbentuk abstrak dalam kain tenun Tanimbar umumnya berupa ragam hias tumbuhan, manusia dan ikan. Ragam hias dalam bentuk-bentuk abstrak pada kain tenun Tanimbar ditunjukkan dalam gambar-gambar berikut:
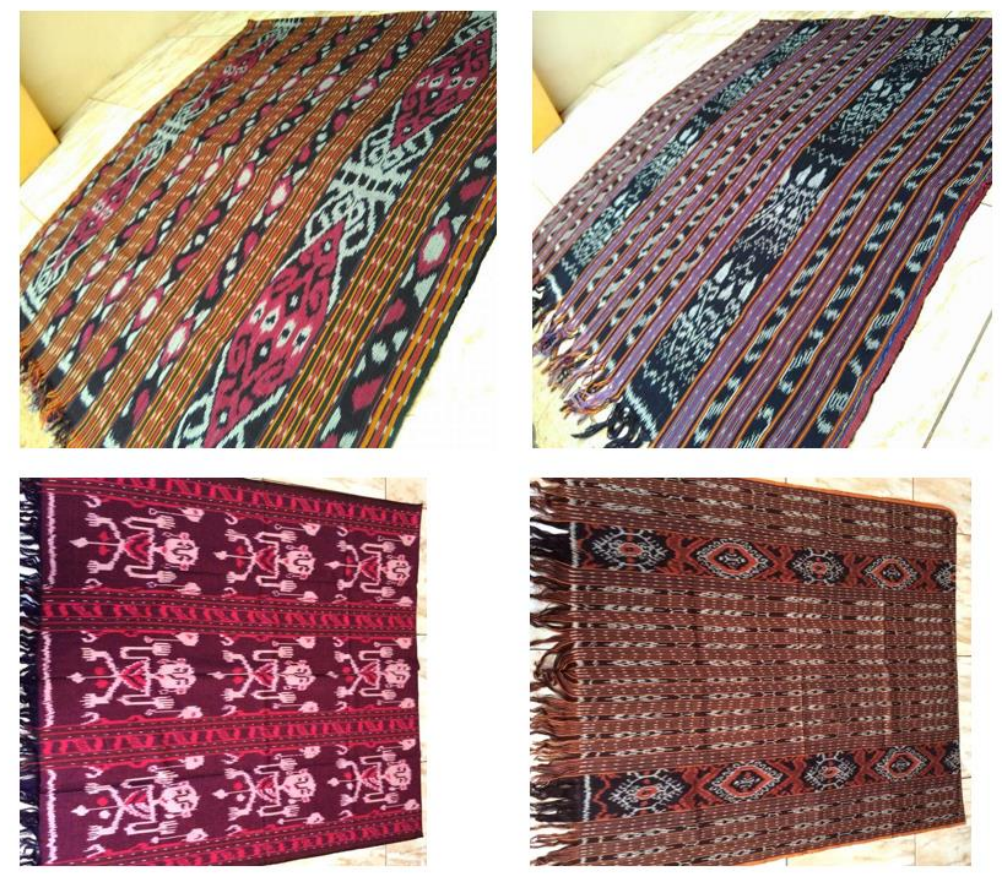

Gambar 5. Contoh-contoh pola kain tenun Tanimbar

Van Vuuren dalam [3] mengatakan bahwa motif dari gambar manusia pada kain tenun Tanimbar melambangkan para leluhur atau roh tertentu yang disembah oleh masyarakat lokal. Motif tumbuhan atau bunga melambangkan alam sekitarnya. Sedangkan motif ikan melambangkan hasil laut yang menjadi salah satu makanan pokok dan juga simbol dari mata pencarian sebagian besar masyarakat Tanimbar yang tinggal di pesisir pantai yang berprofesi sebagai nelayan. 


\section{Hasil dan Pembahasan}

\subsection{Konsep Geometri Fraktal Dalam Kain Tenun Tanimbar}

Pada bagian ini akan dikaji konsep geometri fraktal dalam pola yang terbentuk pada kain tenun Tanimbar. Kajian tersebut ditunjukkan dalam gambar-gambar yang disertai penjelasan.

a. Pola yang terbentuk dari motif gambar manusia

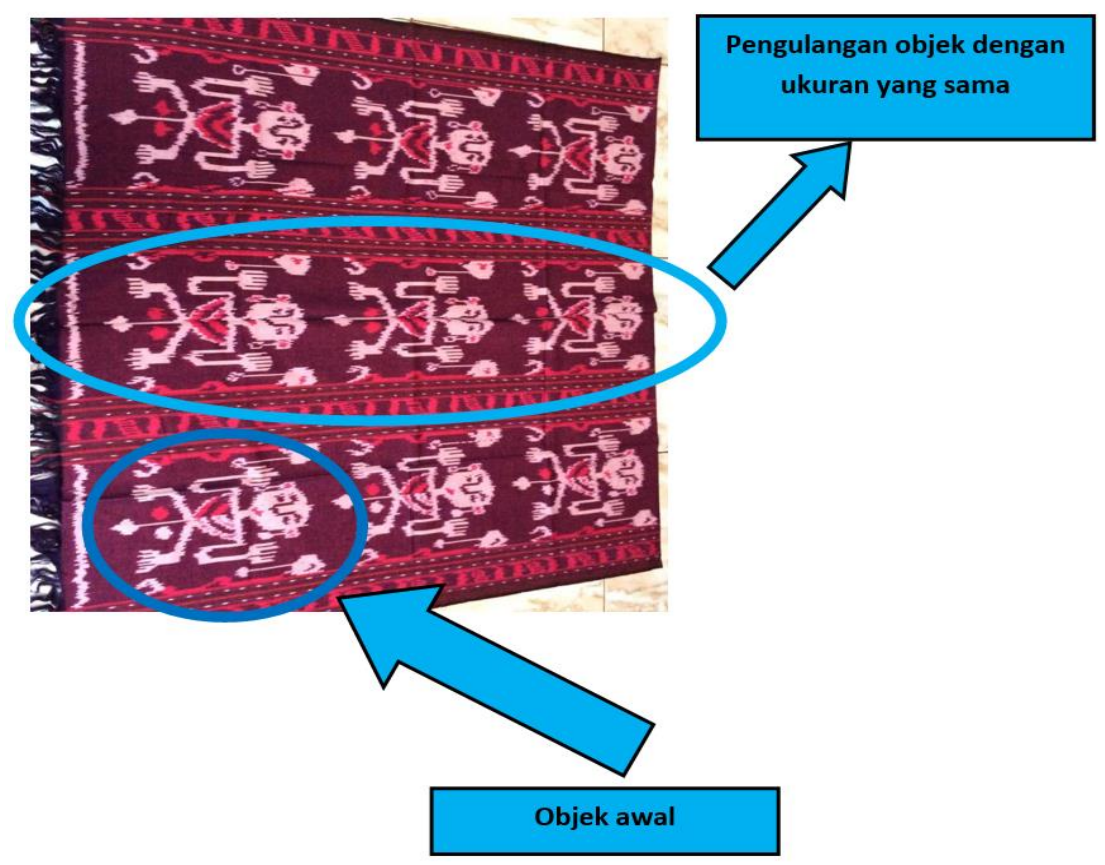

Gambar 6. Pola bentuk abstrak gambar manusia yang terbentuk dari pengulangan objek dengan ukuran yang sama

Dari gambar 6, terlihat bahwa objek dasar pada kain tenun tersebut merupakan bentuk abstrak dari manusia. Objek tersebut diproyeksikan berulang dengan ukuran yang sama sehingga terbentuk suatu pola. Teknik proyeksi objek yang dilakukan pada kain tenun mirip dengan konsep dasar dari geometri fraktal, yaitu kemiripan diri sendiri dan ukuran.

\section{b. Pola yang terbentuk dari motif gambar ikan}

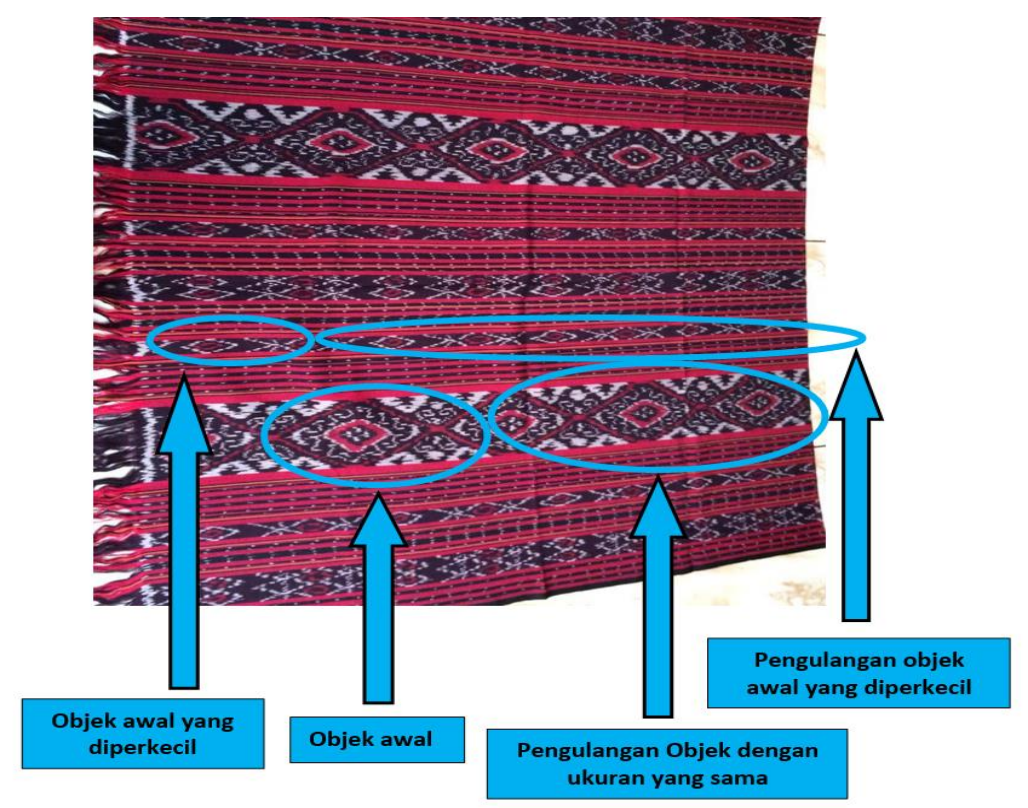

Gambar 7. Pola kain tenun yang dibuat dari pengulangan bentuk abstrak gambar ikan dengan ukuran yang berbeda 
Pada gambar 7, objek dasar dari pola yang terbentuk adalah gambar abstrak dari ikan. Objek dasar tersebut kemudian diproyeksi berulang dengan ukuran yang sama dan ukuran yang diperkecil sehingga membentuk pola yang unik.

\section{c. Pola yang terbentuk dari motif gambar tumbuhan}

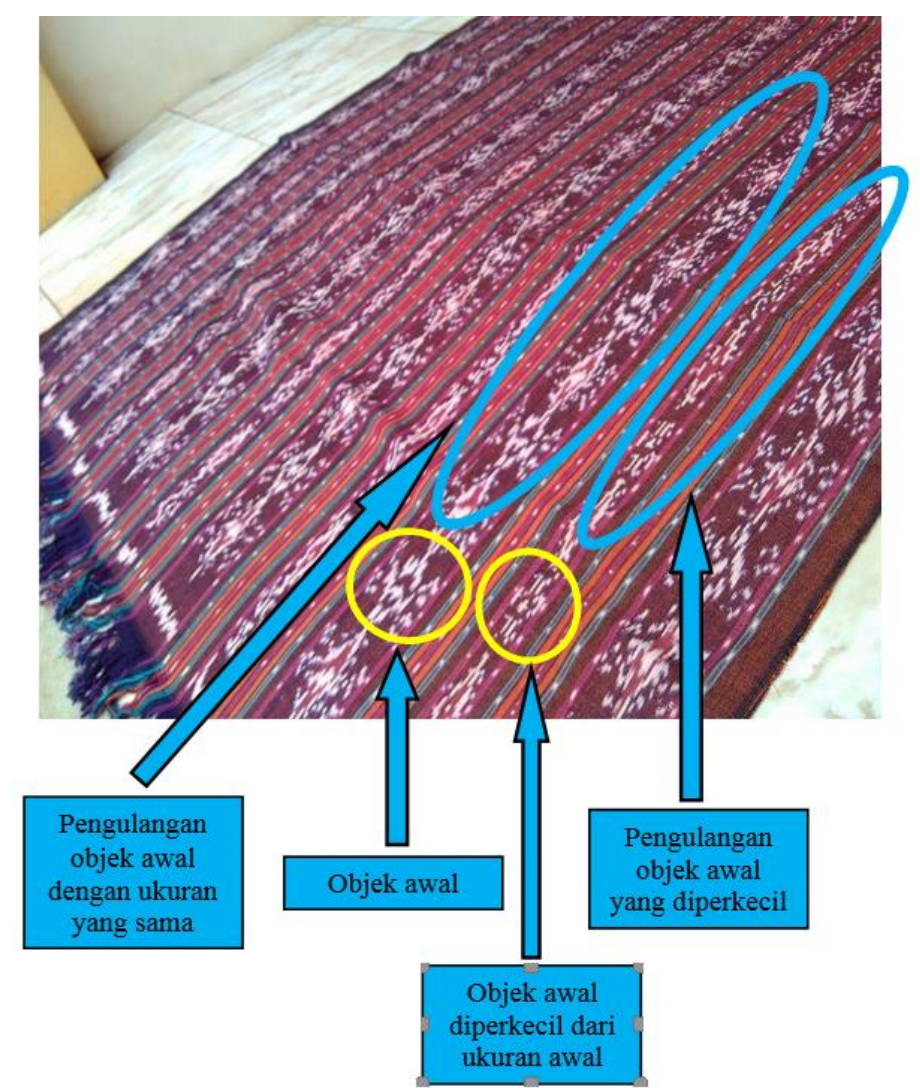

Gambar 8. Pola kain tenun yang dibentuk dari pengulangan bentuk gambar abstrak dari sejenis bunga

Pada gambar 8, terlihat bahwa gambar pada kain merupakan bentuk abstrak dari sejenis tumbuhan. Objek dasar berupa bentuk abstrak dari tumbuhan kemudian diproyeksi berulang dalam ukuran yang sama dan ukuran yang berbeda pada kain sehingga terbentuk suatu pola.

Dari gambar 6-8, dapat dilihat bahwa pola yang ada pada kain-kain tenun dibuat dari suatu objek yang diproyeksi secara berulang dengan ukuran yang sama dan ukuran yang berbeda. Proyeksi yang dilakukan dalam membuat motif gambar pada kain-kain tenun tersebut mengacu pada dua hal dasar, yaitu kemiripan diri sendiri dan ukuran yang sama maupun berbeda. Dua hal dasar yang digunakan dalam membuat pola pada kain tenun Tanimbar tersebut sangat mirip dengan konsep dasar dari geometri fraktal, yaitu kemiripan diri sendiri (self-similarity) dan ukuran (dimension).

\section{Kesimpulan} berikut:

Dari kajian yang telah dilakukan pada pembahasan, maka dapat disimpulkan beberapa hal sebagai

a. Motif yang terbentuk pada kain tenun Tanimbar menunjukkan adanya pengulangan suatu objek dalam ukuran yang sama maupun berbeda sehingga membentuk suatu pola. Pengulangan suatu objek dalam ukuran yang sama atau berbeda menunjukkan kemiripan dengan konsep geometri fraktal.

b. Leluhur masyarakat Tanimbar dalam kehidupan sehari-harinya, tanpa mereka sadari, telah menerapkan konsep geometri fraktal. Mereka telah memiliki imajinasi bagaimana membuat suatu objek yang diproyeksi berulang dalam berbagai ukuran sehingga membentuk suatu pola. Imajinasi tersebut tercermin dalam produk kain tenun Tanimbar. 


\section{Daftar Pustaka}

[1] M. E. Gaddis and M. J. Zyda, The Fractal Geometry of Nature: Its Mathematical Basis and Application to Computer Graphics, California: Naval Postgraduate School, 1986.

[2] B. B. Mandelbrot, Fractals and the Geometry of Nature. Year Book of Science and the Future, New York: Encyclopedia Britania Inc., 1981.

[3] B. B. Mandelbrot, The Fractal Geometry of Nature, New York: W. H. Freeman and Co., 1982.

[4] L. C. Joseph, Mengenal Tenun Tradisional Daerah Maluku, Ambon: Proyek Pengembangan Permuseuman Maluku, 1982.

[5] M. Van Vuuren, Strengen Naar De Voorouders - Een begin tot Inventarisatie van Ikatmotieven van de TanimbarEinlanden, Den Haag: Cip-Gegevens Koninklijke Bibliotheek, 1995. 